\section{Physico-chemical characteriza- tion and antimicrobial activity of Ceiba pentandra (Kapok) seed oil}

\author{
Ravi Kiran Chekuboyina, \\ Koteswara Rao Pagolu, \\ Bhaskar Rao Dadi, Sirisha Nagala, \\ Raghava Rao Tamanam \\ Department of Biochemistry, College \\ of Science and Technology, Andhra \\ University, India
}

\section{Abstract}

Oil extracted from Ceiba pentandra seed was studied to explore its suitability for ethnomedical uses with a special emphasis on its physiochemical characterization, antimicrobial behavior and spectrophotometric parameters. Some of the physiochemical properties were examined and compared with those of standard oils and, in particular, any common characteristics with cotton seed oil were evaluated. Spectrophotometric analysis of oil was carried out to obtain information regarding the types, numbers and position of chromophores and auxochrome, and saturated and unsaturated compounds. Crude Ceiba pentandra oil was found to show good to moderate activity against bacteria, and in particular Gram +ve (B. cereus, B. subtilis and $S$. aureus) and Gram -Ve (E. coli and $P$. aeurignosa) and fungal stains, more specifically Aspergillus flavans, Aspergillus niger, Candida albicans and Saccharomyces cerevisiae. Maximum activity was observed on bacterial strains compared with fungal strains. Among bacteria, Bacillus subtilis was highly sensitive; fungi were less susceptible to oil and Saccharomyces cerivisiae were the most susceptible. Minimum inhibitory concentrations and minimum bactericidal and fungicidal concentrations of the seed oil varied between 3 to $10 \mathrm{mg} / 50 \mu \mathrm{L}$ against all bacterial and fungal strains used in this study. In conclusion, Ceiba pentandra oil is a natural antimicrobial agent and could have therapeutic potential.

\section{Introduction}

The progress of pathogenic microorganism resistance to currently existing antibiotics has led to a search for new antimicrobial agents. ${ }^{1}$ Pathogens are extremely adjustable organisms because of the extremely short time required for generation and their tendency to allocate genetic information, even among diverse species of pathogens. An antibiotic may perhaps kill most of the pathogenic organisms in a certain environment but the resistant survivors can ultimately restore themselves and pass their resistance genes on to their offspring, or even, as often happens, to other species of bacteria. Both medical and veterinary use of antibiotics has led to the manifestation of resistant strains of pathogens. Resistant human pathogens may make it difficult to treat some diseases. However, if the resistant bacteria are not human pathogens, they may still put the patient at risk since they can relocate their antibiotic resistance genes to new pathogenic microorganisms. ${ }^{2}$

The overuse of antibiotics in dealing with infectious ailments, and the appearance of multi-drug resistant pathogenic strains, has stimulated research towards the study of antimicrobial agents from essential oils. ${ }^{3,4} \mathrm{~A}$ few essential oils have antimicrobial activities and some oils are used in cancer treatment, 5,6 food preservation, ${ }^{7}$ aromatherapy, ${ }^{8}$ and in the perfume industry. ${ }^{9}$ Essential oils are a rich source of biologically active compounds. Therefore, it is sensible to already have identified a variety of plant compounds in these oils, with precise as well as broad antimicrobial activities, for possible future therapeutic use.

Therefore, the first objective of this study was to identify some physiochemical characteristics and antimicrobial activities of Ceiba pentandra seed oil using spectrophotometric analysis. Ceiba pentandra is a tree found in the steamy emergent layer of rainforests. It belongs to the Malvaceae (Malvalea) family. It is found extensively all over the world, from tropical America to Asia through Africa, and on farms in Southeast Asia, Western South India, Sri Lanka and other parts of East Asia and Africa. It is being used as a conventional medicine for the treatment of several disorders, such as headache, dizziness, diabetes, diuretic, fever, hypertension, constipation, mental disorders, peptic ulcer, rheumatism and leprosy. 10

\section{Materials and Methods}

\section{Seed collection}

Mature dried fruits of Ceiba pentandra were obtained from the area in and around Andhra University, Visakhapatnam, India, and were explored for physiochemical characterization, antimicrobial activities and for spectrophotometric analysis.

\section{Soxhlet extraction}

The seed oil was extracted using a soxhlet
Correspondence: Ravi Kiran Chekuboyina, Department of Biochemistry, College of Science and Technology, Andhra University, Visakhapatnam-530003, India.

$\mathrm{Tel} / \mathrm{Fax}: 0891.284 .4542$.

E-mail:ravi79biochem@gmail.com

Key words: antimicrobial activity, auxochrome broth dilution method, Ceiba pentandra seed oil, chromophores.

Conflict of interests: the authors report no poten tial conflict of interests.

Received for publication: 28 April 2012.

Revision received: 28 May 2012.

Accepted for publication: 2 June 2012.

This work is licensed under a Creative Commons Attribution NonCommercial 3.0 License (CC BYNC 3.0).

(C) Copyright R.K. Chekuboyina et al., 2012

Licensee PAGEPress, Italy

Alternative Medicine Studies 2012; 2:e9

doi:10.4081/ams.2012.eg

extraction method with analytical grade hexane as a refluxing solvent. On completion of the extraction process, the oil was recovered from the mixture by distillation and stored at $40 \mathrm{C}$ until use. 11

The percentage of oil content can be calculated as follows:

$$
\% \text { of oil }=\frac{\text { Wt. oil obtained in grams }}{\text { Wt. seed taken in grams }} \times 100
$$

\section{Oil characterization}

The crude oil sample obtained from the hexane extraction was characterized for acid value, saponification value, iodine value, peroxide value. Reichert-Meissl value (RMV) and Polenske value were based on official recommendations and Tentative Methods of the American Oil Chemist's Society. ${ }^{12}$

\section{Spectrophotometric analysis}

Ultraviolet (UV) and visible absorption spectra were carried out for the Ceiba pentandra extracted oil. Absorption was between 200-300 $\mathrm{nm}$ and $300-600 \mathrm{~nm}$ wave lengths in a quartz cell with $1 \mathrm{~cm}$ path length against a solvent blank in a matched cell using Shimadzu double beam UV using a visible spectrophotometer, model TCC240A with UV probe software. ${ }^{13}$

\section{Antimicrobial activity}

\section{Microorganisms}

The oil of Ceiba pentandra was individually tested on nine different pathogenic microorganisms. Five were bacteria: Bacillus cereus MTCC430, Bacillus subtilis MTCC441, Escheri - 
chia coli MTCC443, Pseudomonas aeruginosa MTCC424 and Staphylococcus aureus MTCC3160. Four were fungal strains: Aspergillus flavans MTCC3396, Aspergillus niger MTCC961, Candida albicans MTCC227 and Saccharomyces cerevisiae MTCC170. These were obtained from the microbial culture collection center in Chandigarh, India.

\section{Inoculum preparation}

Bacterial strains were maintained on nutrient agar. Overnight cultures of the bacterial strains were prepared in nutrient broth and they were incubated for $24 \mathrm{~h}$ at $37^{\circ} \mathrm{C}$ before use and standardized to $0.5 \mathrm{Mc}$ Farland standards $\left(10^{6}\right.$ cfumL $\left.^{-1}\right)$. The fungal isolates were grown on PDA at $25^{\circ} \mathrm{C}$ until they were sporulated. The fungal spores were harvested after sporulation by pouring a mixture of sterile glycerol and distilled water on the surface of the plate and the spores were later scraped with a sterile glass rod. The harvested fungal spores were standardized to a concentration of $10^{6}$ spores/mL or to an $\mathrm{OD}_{600 \mathrm{~nm}}$ of 0.1 before use. ${ }^{14}$

\section{Agar well diffusion method}

Antimicrobial assay was carried out by an agar well diffusion method. ${ }^{15,16}$ Twenty milliliters $(20 \mathrm{~mL})$ of the molten nutrient agar were seeded with $100 \mu \mathrm{L}$ inoculum of the test organism in sterile petri dishes rotated slowly to ensure a uniform distribution of the microorganisms, and allowed to solidify on the bench for $30 \mathrm{~min}$. The seed oil of Ceiba pentandra was dissolved in hexane to a final concentration of $200 \mathrm{mg} / \mathrm{mL}$. The 6 -mm wells were cut from the agar surface and each well was inoculated with $50 \mu \mathrm{L}$ of the extract at a concentration of $10 \mathrm{mg}$ well-1. After the incubation period $(24 \mathrm{~h}$ at $370 \mathrm{C}$ for bacteria and $25^{\circ} \mathrm{C}$ for $96 \mathrm{~h}$ for fungi), wells were observed for zones of inhibition. The effect of extract on bacterial and fungal isolates was compared with those of rifampicin and fluconazole at a concentration of $1 \mathrm{mg} / \mathrm{mL}$.

\section{Minimum inhibitory concentration}

Minimum inhibitory concentrations (MIC) of oil were prepared in test tubes using a broth dilution method.17 Fifty microliters of Ceiba pentandra seed oil at concentrations of $1,2,3$, $4,5,6,7,8,9,10 \mathrm{mg} / 50 \mu \mathrm{L}$ was added to $5 \mathrm{~mL}$ of nutrient broth for the bacterial strains and potato dextrose broth for the fungi containing cells as described above. A negative control tube was inoculated without extract. The test tubes were incubated for $24 \mathrm{~h}$ at $37^{\circ} \mathrm{C}$ for bacteria and $48 \mathrm{~h}$ at $25^{\circ} \mathrm{C}$ for fungi. During the incubation period, the tubes were submitted to a manual agitation every hour. After incubation, the MIC was recorded as the lowest concentration demonstrating no apparent growth compared to the negative control.18

\section{Minimum bactericidal and fungicidal concentration}

The bactericidal and fungicidal concentration of the oil was determined by a modification of the broth microdilution method according to the German DIN regulation 58940-7. Samples were taken from test tubes with no visible growth in the MIC assay, subcultured on freshly prepared nutrient agar plates and potato dextrose agar plates, and later incubated at $37^{\circ} \mathrm{C}$ for $48 \mathrm{~h}$ and $25^{\circ} \mathrm{C}$ for $72 \mathrm{~h}$ for bacteria and fungi, respectively. The minimum bactericidal and fungicidal concentrations were taken as the concentrations of oil that did not show any growth on a set of agar plates.

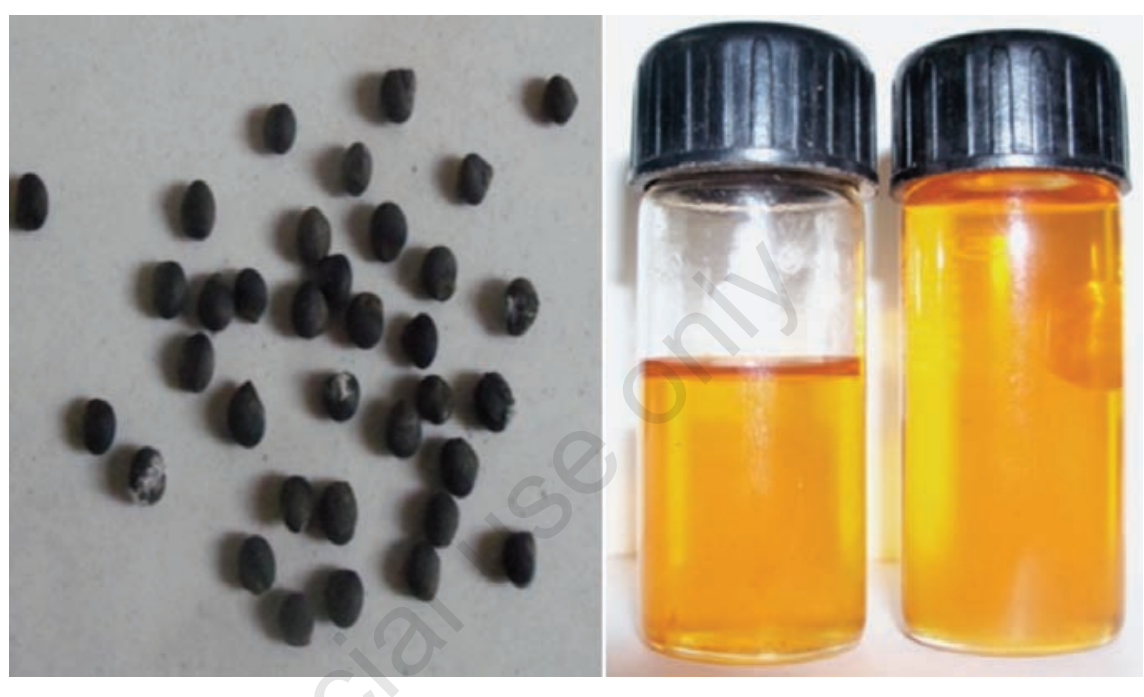

Figure 1. Ceiba Pentandra seeds and oil.

Table 1. Some physiochemical properties of Ceiba pentandra seed oil.

\begin{tabular}{lll} 
S/No & Parameter & Value \\
1 & Color & Yellow \\
2 & Odor & Pungent \\
\hline 3 & Yield (\%) & $40 \%$ \\
4 & PH & Acidic \\
\hline 5 & Acid value $(\mathrm{mg} \mathrm{KOH} / \mathrm{g})$ & 15 \\
6 & Saponification value $(\mathrm{mg} \mathrm{KOH} / \mathrm{g})$ & 224 \\
\hline 7 & Iodine value & 98 \\
8 & Peroxide value & $12 \mathrm{mEqKg}-1$ \\
\hline 9 & Reichert-Meissl value & 0.36 \\
& Polenske value & 0.97 \\
\hline
\end{tabular}

Table 2. Minimum inhibitory concentrations and minimum bactericidal and fungicidal concentrations.

\begin{tabular}{|c|c|c|c|c|c|}
\hline Bacteria & $\begin{array}{c}\text { MIC } \\
(\mathrm{mg} / \mathrm{hL})\end{array}$ & $\begin{array}{c}\mathrm{MBC} \\
(\mathrm{mg} / \mathrm{HL})\end{array}$ & Fungi & $\begin{array}{c}\text { MIC } \\
\text { (mg/pL) }\end{array}$ & $\begin{array}{c}\text { MFC } \\
(\mathrm{mg} / \mathrm{pL})\end{array}$ \\
\hline B. cereus $(\mathrm{Gram}+)$ & 0.08 & 0.08 & A. flavus & 0.16 & 0.16 \\
\hline B. subtilis (Gram +) & 0.06 & 0.06 & A. niger & 0.18 & 0.18 \\
\hline S. aureus (Gram+) & 0.08 & 0.08 & C. albicans & 0.20 & 0.20 \\
\hline E. coli (Gram-) & 0.08 & 0.08 & S. cerevisiae & 0.08 & 0.08 \\
\hline
\end{tabular}

\begin{tabular}{lll} 
P. aeurignosa (Gram -) & 0.08 & 0.08 \\
\hline MIC, minimum inhibitory concentrations; $\mathrm{MBC}$, minimum bactericidal concentrations; $\mathrm{MFC}$, minimum bactericidal concentrations.
\end{tabular}



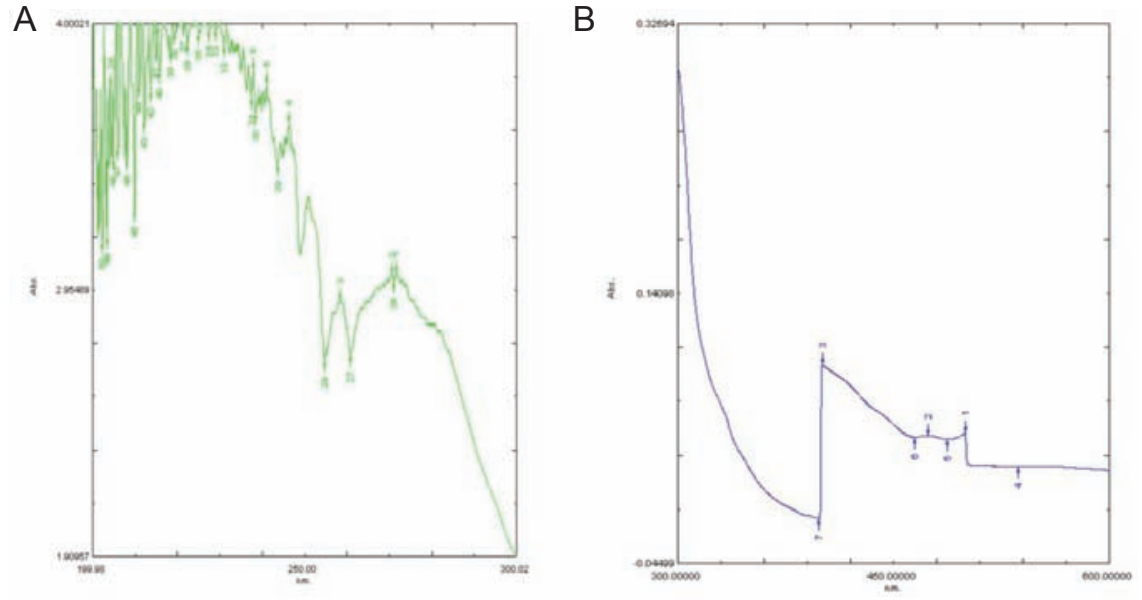

Figure 2. UV-Vis absorption spectrum of Ceiba pentandra seed oil. A) Absorption spectra from $200 \mathrm{~nm}$ to $300 \mathrm{~nm}$; B) Absorption spectra from $300 \mathrm{~nm}$ to $600 \mathrm{~nm}$.

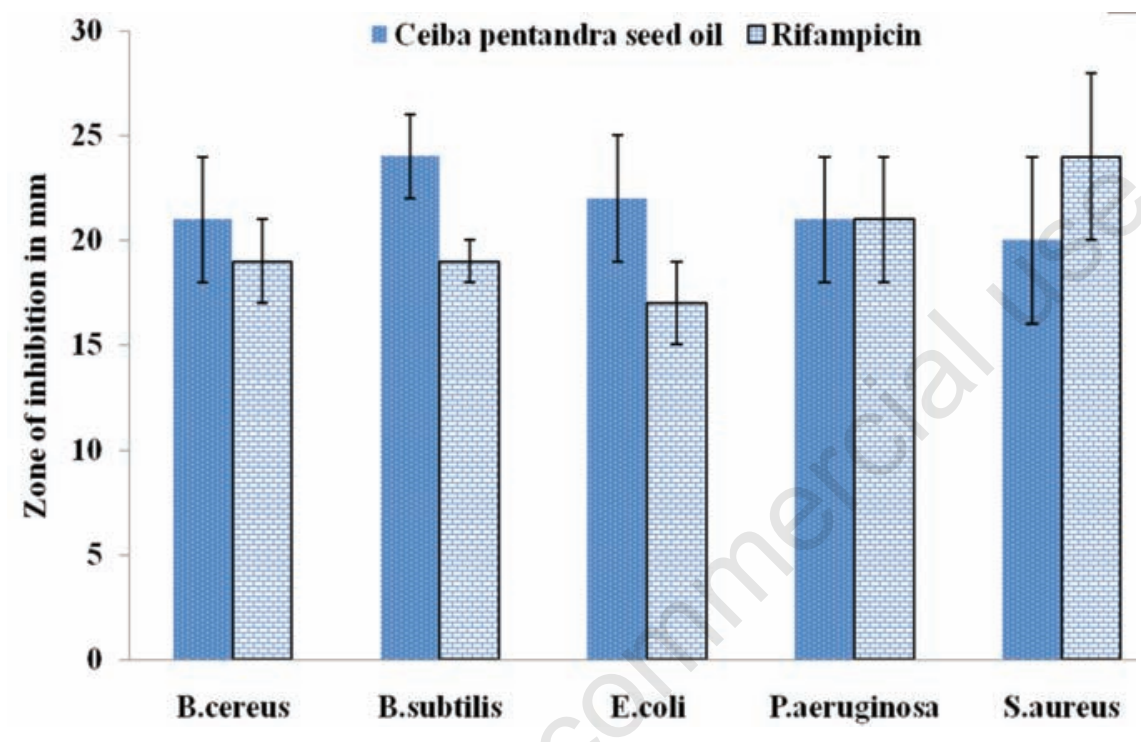

Figure 3. Antibacterial activity of Ceiba pentandra seed oil. Values represent average of triplicates and are expressed as mean \pm standard deviation.

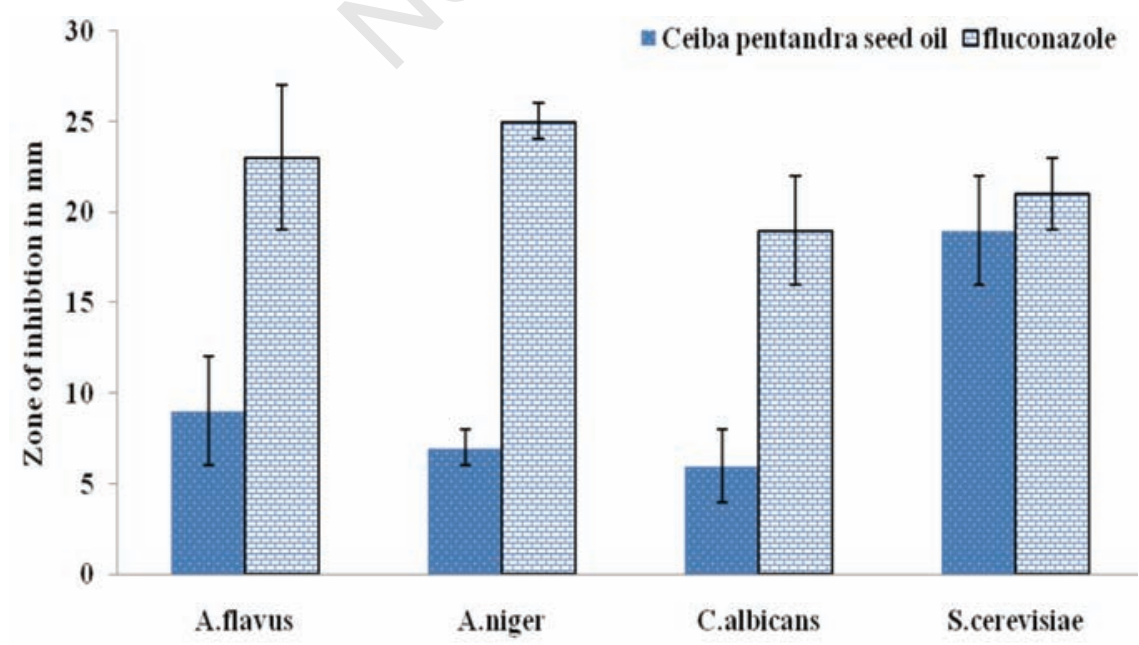

Figure 4. Antifungal activity of Ceiba pentandra seed oil. Values represent average of triplicates and expressed as mean \pm standard deviation.

\section{Results and Discussion}

\section{Physiochemical characterization}

Oil extraction was carried out by a soxhlet extraction method according to Association of Official Analytical Chemists - AOAC - recommendations. Hexane was used as solvent to extract the oil from seeds and this was passed out for $10 \mathrm{~h}$. The physiochemical characteristics were comparable to that of cotton seed oil (Table 1). The oil was thick and yellowish in color with a pungent odour and a $40 \%$ yield (Figure 1). The acid value of the oil was predicted to be 15 , analogous to that of butter (0.46-35.0). The iodine value (degree of unsaturation) of the Ceiba pentandra seed oil was 98 , comparable to that of cotton seed oil (103111).The saponification value of the oil was 196, identical to that of cotton seed oil (194196). Peroxide value, which indicates the extent of oil oxidation, was $12 \mathrm{mEqKg}^{-1}$. Fresh edible oils have a peroxide value of less than 10 $\mathrm{mEqKg}-1$, while rancid oils have values of more than $20 \mathrm{mEqKg}-1$. The RMV of the oil was 0.36 , the same as volatile water-soluble fatty acids present in the oil or fat. Relatively lower RMV of the oil was an indication of low content steam volatile fatty acids. The Polenske value of the oil was 0.97 , which indicates low content of the volatile alcohol-soluble fatty acids in the oil.

\section{Spectrophotometric analysis}

UV-visible spectrum can be applied to identify the types, numbers and position of chromophores and auxochrome, and saturated and unsaturated compounds. UV-Vis absorption spectrums of Ceiba pentandra seed oil are shown in Figure 2. If no absorption peaks between $200 \sim 400 \mathrm{~nm}$ were detected, there is no conjugate double bond and $\mathrm{C}=0$ group, demonstrating that this is most probably a saturated compound. If there is a weak peak $(=10 \sim 100)$ between $270 \sim 350 \mathrm{~nm}$, and no other peaks detected over $200 \mathrm{~nm}$ it may contain $>\mathrm{C}=0$, $>\mathrm{C}=\mathrm{C}-\mathrm{O}$ - or $>\mathrm{C}=\mathrm{C}-\mathrm{N}<$ etc. The weak peak was due to $\mathrm{n}-*$ transition. If there are many peaks in the UV region, some of them are even within the visible region, then the compounds may have long conjugation bonds. When $\lambda_{\max }$ is over $250 \mathrm{~nm}$, and is between 1000 10000, the compound may contain aromatic structure. $\varepsilon$ between $10000 \sim 20000$ for the long wave absorption peak may be conjugated diene or carbonyl compounds. ${ }^{19}$ If the peaks appear at the wavelengths 425,455 and $480 \mathrm{~nm}$ in addition to 525,570 and $590 \mathrm{~nm}$ chromophores, they may belong to carotenoids and flavonoids. ${ }^{20}$ Given this, Ceiba pentandra crude oil may have unsaturated fatty acids with tandem conjugated double bonds, alkaloids, carotenoids, flavonoids, tannins and phenolic compounds, confirming its therapeutic potential. 


\section{Antimicrobial activity}

In the present study, Ceiba pentandra seed oil in general showed antimicrobial activity against all the pathogenic bacterial and fungal strains studied. The bacteria and fungus used in this study were associated with various forms of diseases. ${ }^{21}$ The antimicrobial and antifungal activity of the essential oil of L. nobilis has been demonstrated previously.22 Simic et al. ${ }^{22}$ reported low antifungal activity. In the present study, we found that the Ceiba pentandra seed oil showed significant action on bacterial strains compared with fungal strains (Figures 3 and 4). Results of antimicrobial susceptibility revealed that Bascillus subtilis was the most susceptible with an inhibition zone diameter (mm) of $24 \pm 2$ followed by Eschirichia coli (22 \pm 3$)$, Pseudomonas aeruginosa (21 \pm 3$)$, Bacillus cereus $(21 \pm 3)$, and Staphylococcus aureus $(20 \pm 4)$. Among fungi, Sacharomycetus cerevisiae was the most susceptible with an inhibition zone diameter (mm) of $19 \pm 3$ followed by Aspergillus flavans $(9 \pm 3)$, Aspergillus niger $(7 \pm 1)$ and Candida albicans $(6 \pm 2)$. MICs and minimum bactericidal and fungicidal concentrations of the seed oil are shown in Table 2 . These varied between $3-10 \mathrm{mg} / 50 \mu \mathrm{L}$ against all bacterial and fungal strains used in this study. The varying degrees of susceptibilities of the bacterial and fungal strains may be due to the intrinsic tolerance of the microorganisms, and the nature and combinations of phyto compounds present in the oil. That fatty acids are potent antimicrobial agents with an inhibitory action has long been known. ${ }^{23}$ Trace amounts of fatty acids have been shown to influence the growth of microorganisms in a very specific manner; some fatty acids, such as lauric acid, have been shown to have greater inhibitory action than others. ${ }^{24}$ Kabara and coworkers examined several specific straight-chain saturated fatty acids and found lauric acid to be one of the most potent bacteriostatic fatty acids when tested on gram positive organisms. ${ }^{25}$ In a study by Gudmundur et al., ${ }^{26}$ capric acid was found to inhibit the growth of Candida albicans, a fungal organism responsible for many infections. Medium chain free fatty acids and their corresponding 1-monoglyrides have been found to have a broad spectrum of microbicidal activity against enveloped viruses and various bacteria in vitro, 27,28 including pathogens such as herpes simplex virus, ${ }^{29}$ Neisseria gonorrhoeae, ${ }^{30}$ Chlamydia trachomatis, group A streptococci, group B streptococci, and Staphylococcus aureus. ${ }^{31}$ An important characteristic of essential oils and their components is their hydrophobosity which enables them to partition the lipids of the bacterial cell membrane and mitochondria, disturbing the cell structures and rendering them more permeable. 32 Extensive leakage from bacterial cells or the exit of critical molecules and ions will lead to death. 33 The activity of the essential oils would be expected to relate to the structural configuration of the constituent components of the volatile oils and their functional groups and possible synergistic interactions between components. ${ }^{34}$ There were some reports about antimicrobial activity of terpinen-4ol, eugenol, and linalool components. ${ }^{22,35}$ Indeed, the antibacterial activity of crude extracts has been attributed to the presence of some of the phytochemical components such as alkaloids, flavonoids, saponins and tannins which was in agreement with our results. 36,37

\section{Conclusions}

The ethnomedicinal study of seed oils is important for modern day medicine but its usefulness cannot be fully appreciated until methods of comparison with other compounds are standardized and reproducible results are obtained. The present study has revealed the importance of seed oils in controlling resistant bacteria and fungi which are becoming a threat to human health. This can serve as a useful platform for the development of inexpensive, safe and effective natural medicines.

\section{References}

1. Hsueh PR, Chen WH, Luh KT. Relationships between antimicrobial use and antimicrobial resistance in Gram-negative bacteria causing nosocomial infections from 1991-2003 at a university hospital in Taiwan. Int $\mathbf{J}$ Antimicrob Agents 2005;26:463-72.

2. Tepe B, Daferera D, Sokmen M, et al. In vitro antimicrobial and antioxidant activities of the essential oils and various extracts of Thymus eigii M. Zohary et P.H. Davis. J Agric Food Chem 2004;52:1132-7.

3. Arias ME, Gómez JD, Cudmani NM, et al. Antibacterial activity of ethanolic and acqueous extract of Acacia aroma Gill. ex Hook et Arn. Life Sci 2004;75:191-202.

4. Kloucek P, Polesny Z, Svobodova B, et al. Antibacterial screening of some Peruvian medicinal plants used in Callería District. J Ethnopharmacol 2005;99:309-12.

5. Burt SA. Essential oils: their antibacterial properties and potential applications in foods: a review. Inter J Food Microbiol 2004;94:223-53.

6. Sylvestre M, Pichette A, Longtin A, et al. Essential oil analysis and anticancer activity of leaf essential oil of Croton flavens L. from Guadeloupe. J Ethnopharmacol 2006;103:99-102.
7. Faid M, Bakhy K, Anchad M, et al. Almond paste: physicochemical and microbiological characterization and preservation with sorbic acid and cinnamon. J Food Protect 1995;58:547-550.

8. Buttner MP, Willeke K, Grinshpun SA. Sampling and analysis of airborne microorganisms. In: Manual of environmental microbiology. Hurst CJ, Knudsen GR, McInerney MJ, et al. Washington, DC: ASM Press; 1996. pp. 629-640.

9. Van de Braak SAAJ, Leijten GCJJ. Essential oils and oleoresins. A Survey in the Netherlands and other major markets in the European Union. Rotterdam: CBI, Centre for the Promotion of Imports from Developing Countries; 1999. p. 116.

10. Lim TT, Huang X. Evaluation of kapok (Ceiba pentandra (L.) Gaertn.) as a natural hollow hydrophobic-oleophilic fibrous sorbent for oil spill cleanup. Chemosphere 2007;66:955-63.

11. Popoola TOS, Yangomodou OD, Akintokun AK. Antimicrobial activity of cassava seed oil on skin pathogenic microorganisms. Research Journal of Medicinal Plant 2007;1:60-4.

12. AOCS. Official methods and recommended practices of the AOCS, 5th edition. Champaign, IL: American Oil Chemists' Society; 1998.

13. Vogel AI. Vogel's textbook of practical organic chemistry, including qualitative organic analysis. 4th Ed. London: Longman Group Ltd.; 1978.

14. Coulidiati TH, Millogo-Kone H, LamienMeda A, et al. antioxidant and antibacterial activities of two Combretum species from Burkina Faso. Research Journal of Medicinal Plant 2011;5:42-53.

15. Ojala T, Remes S, Haansuu P, et al. Antimicrobial activity of some coumarin containing herbal plants growing in Finland. J Ethnopharmacol 2000;73:299305.

16. Chanda S, Kaneria M, Nair R. Antibacterial activity of Psoralea corylifolia L. seed and aerial parts with various extraction methods. Res J Microbiol 2011;6:124-31.

17. De N, Ifeoma E. Antibacterial effects of components of the bark extract of neem (Azadirachta indica A. Juss) Technol Dev 2002;8:23-8.

18. Rasooli I, Rezaei MB, Allameh A. Growth inhibition and morphological alterations of Aspergillus niger by essential oils from Thymus eriocalyx and Thymus x- porlock. Food Control 2006;17:359-64.

19. Pavia DL, Lampman GM, Kris GS. Introduction to spectroscopy. Washington: Thompson Learning; 2002. p. 360.

20. O'Connor RT, Field ET, Jefferson ME, Dollear FG. The influence of processing on the spectral properties of vegetable oils. J 
Am Oil Chemists Soc 1949;26:710-8.

21. Nester EW. Microbiology: a human perspective. 4th ed. New York, NY: McGrawHill Higer Education; 2004. pp. 635-637.

22. Simić A, Soković MD, Ristić M, et al. The chemical composition of some Lauraceae essential oils and their antifungal activities. Phytother Res 2004;18:713-7.

23. Bayliss M. Effect of the chemical constitution of soaps upon their germicidal properties. J Bacteriol 1936;31:489-504.

24. Nieman C. Influence of trace amounts of fatty acids on the growth of microorganisms. Bacteriol Rev 1954;18:147-61.

25. Kabara JJ, Swieczkowski DM, Conley AJ, Truant JP. Fatty acids and derivatives as antimicrobial agents. Antimicrob Agents Chemother 1972;2:23-8.

26. Bergsson G, Arnfinnsson J, Steingrímsson 0, Thormar H. In vitro killing of Candida albicans by fatty acids and monoglycerides. Antimicrob Agents Chemother 2001;45:3209-12.

27. Isaacs CE, Litov RE, Thormar $H$. Antimicrobial activity of lipids added to human milk, infant formula, and bovine milk. J Nutr Biochem 1995;6:362-6.

28. Kabara JJ. Fatty acids and derivatives as antimicrobial agents. In: The pharmacological effect of lipids. St. Louis, M0: American oil chemist's society; 1978. pp 114.

29. Thormar H, Isaacs CE, Brown HR, et al. Inactivation of enveloped viruses and killing of cells by fatty acids and monoglycerides. Antimicrob Agents Chemother 1987;31:27-31.

30. Bergsson G, Steingrimsson 0, Thormar H. In vitro susceptibilities of Neisseria gonorrhoeae to fatty acids and monoglycerides. Antimicrob Agents Chemother 1999;43: 2790-2.

31. Bergsson G, Arnfinnsson J, Karlsson SM, et al. In vitro inactivation of Chlamydia trachomatis by fatty acids and monoglycerides. Antimicrob Agents Chemother 1998;42:2290-4.

32. Knobloch $\mathrm{K}$, Weigand $\mathrm{H}$, Weis $\mathrm{N}$, et al. Action of terpenoids on energy metabolism. In: Brunke EJ. Progress in essential oil research: 16th international symposium on essential oils. Berlin: De Gruyter;
1986. pp. 429-445.

33. Denyer SP, Hugo WB. Biocide- induced damage to the bacterial cytoplasmic membranes. In: Mechanisms of action of chemical bio-cides. The Society for Applied Bacteriology, Technical Series No 27. 0xford: Oxford Blackwell Scientific Publication; 1991. pp. 171-188.

34. Dorman HJD, Deans SG. Antimicrobial agents from plants: antibacterial activity of plant volatile oils. J App Microbiol 2000;88:308-16.

35. Ozcan M, Erkmen 0. Antimicrobial activity of the essential oils of Turkish plant species. Eur Food Res Technol 2011;212: 658-60.

36. Musa AM, Abbas G, Aliyu AB, et al. Phytochemical and antimicrobial screening of Indigofera conferta GILLETT (Papilionaceae). Res J Med Plant 2008;2: 74-8.

37. Adebayo-Tayo BC, Ajibesin KK. Antimicrobial activities of Coula edulis. Res $\mathrm{J}$ Med Plant 2008;2:86-91. 